\title{
非線形な復原力曲線を持つ船舶の 向波中横摇れ特性に関する基礎的研究
}

\author{
正会員片 山徹* 学生会員 宮 本 修 吾* \\ 正会員 橋 本 博 公** 正会員 田 井 祥 史 ${ }^{* * *}$
}

\begin{abstract}
A Study on Characteristics of Rolling in Head Waves of a V essel with N onlinear G Z-curve
by Toru Katayama, M ember Shugo M iyamoto, Student Member

Hirotada Hashimoto, M ember Y oshifumi Tai, Member
\end{abstract}

\begin{abstract}
Summary
In this study, the characteristics of rolling in head waves for a vessel with nonlinear GZ-curve, which includes parametric rolling, are investigated. Rolling is measured for systematically changed wave length and height under the same forward speed, which is service speed in heavy weather. As the results, the range of $T_{e} / T_{\phi}\left(T_{e}\right.$ and $T_{\phi}$ are encounter wave period and roll natural period), when periodic rolling occurs, is wider than one of previous results by Taguchi et $\mathrm{al}^{12}$, and the range spreads out wider range of $T_{e} T_{\phi}>0.5$. Especially, in the range of $T_{e} T_{\phi}>0.5$, roll amplitude becomes large, and a periodic rolling occurs at large wave height. It is supposed that the result is caused by the effects of roll amplitude on roll natural period. Then, numerical simulations' ${ }^{2}$ are carried out for some variation of GZ-curves to confirm the measured results. Additionally, roll measurements in superposed waves of two different wave periods and in the irregular wave with Pierson-M oskowitz spectrum are also carried out.
\end{abstract}

\section{1. 緒言}

近年, バラスト水排水の環境影響が問題となっており， ノ ンバラスト船やバラスト水をほとんど積まない船型の研 究・開発が進んでいる.このような船型の一つに, 軽荷状態 での復原性確保を目指した, 幅広浅喫水船がある.

この船型では, 復原力曲線が横傾斜角の増加に伴い線形復 原力に比べて小さくなる非線形性を持つことがあり, そのた め横摇れ振幅角の増加に伴い横摇れ固有周期が長くなり, 従 来の船舶とは異なった横摇れ特性を持つ可能性がある.この ような背景のもと, これまでに同研究グループでは前述の復 原力特性を持つ同船型の規則横波中横摇れ特性について調 查・検討し, 非線形な復原力曲線を持つ船舶に特有の同調曲 線の跳躍現象の発生を確認している ${ }^{31}$.

本研究では, 同船 ${ }^{3)}$ を対象に向波航行時のパラメトリック 横摇れを含む横摇れの発生条件とその特徵について調査し た. まず, 規則向波中で横摇れを計測し, その発生状態を調

\footnotetext{
* 大阪府立大学大学院 工学研究科

** 大阪大学大学院 工学研究科

***今治造船株式会社
}

原稿受理 平成 24 年 4 月 17 日
查した.さらに，不規則向波中および 2 周波数合成波中での 横摇れを計測し, その発生状態について調査した. 最後に, 数值計算により, 前述の復原力曲線の非線形性によってパラ メトリック横摇れが発生することを確認するとともに, 同非 線形性がパラメトリック横摇れの発生条件に与える影響に ついて検討した。

\section{2. 供試船}

供試船の正面線図および主要目をFig.1 と Table 1 に示す. また, 横復原力曲線の計算結果を Fig.2 に示す。同図には線 形復原力も示している. なお, 復原力の計算では, 横傾斜角 毎にまず上下およびトリム方向のつり合い姿勢を求め, この 姿勢に対して復原力を計算した。同船の復原力曲線は, 横傾 斜角 5 度付近で線形復原力に対して2割程度小さくなる非線 形性を示す.この非線形性は, 同船型が大きなビルジ半径と 底勾配を持つ幅広浅喫水船であるため, 比較的小さな横傾斜 角からビルジ部を露出するために生じる.

Fig.3 に, 自由横摇れ減衰試験結果から求めた横摇れ固有 周期と横摇れ振幅角の関係を示す. 同図から, 横摇れ振幅角 の増加に伴い, 横摇れ固有周期が長くなることがわかる.こ れは, Fig.2 に示寸横傾斜角の増加に伴い復原力が線形復原 力に比べて小さくなる復原力曲線の非線形性によるもので ある。 


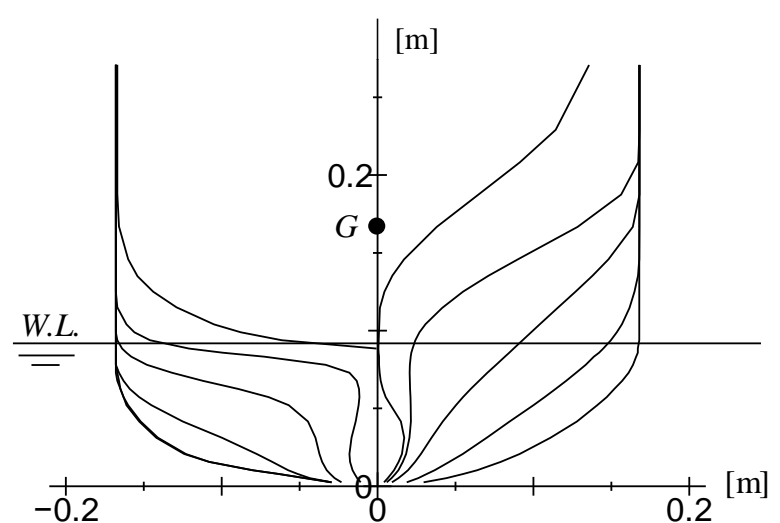

Fig. 1 Body plan of the model.

Table 1 Principal particulars of the model.

\begin{tabular}{|l|c|c|}
\hline & real scale & model scale \\
\hline $\mathrm{L}_{\mathrm{pp}}[\mathrm{m}]$ & 192 & 2.0 \\
\hline $\mathrm{B}[\mathrm{m}]$ & 32.26 & 0.336 \\
\hline $\mathrm{draft}: \mathrm{d}[\mathrm{m}]$ & 9.0 & 0.0938 \\
\hline $\mathrm{KG}[\mathrm{m}]$ & 17.0 & 0.177 \\
\hline $\mathrm{GM}[\mathrm{m}]$ & 1.81 & 0.0189 \\
\hline roll natural period: $\mathrm{T}_{\phi}[\mathrm{sec}]$ & 18.42 & 1.88 \\
\hline breadth of bilge-keels & 0.7 & 0.0073 \\
\hline position of bilge-keels & \multicolumn{2}{|c}{ s.s. 3.34-s.s. 5.59 } \\
\hline
\end{tabular}

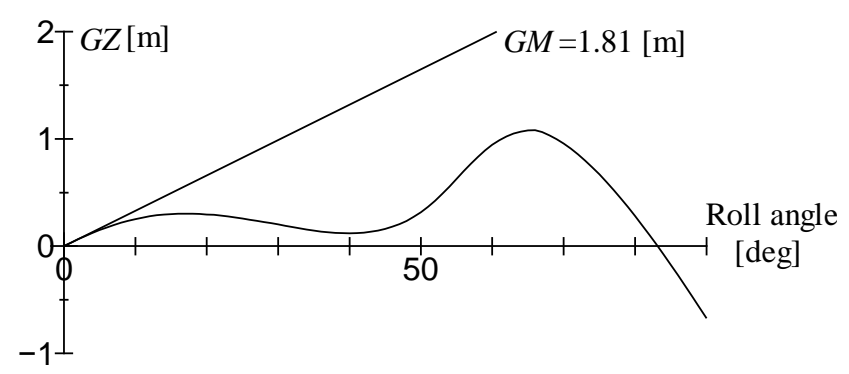

Fig. 2 GZ-curve of the model in real scale.

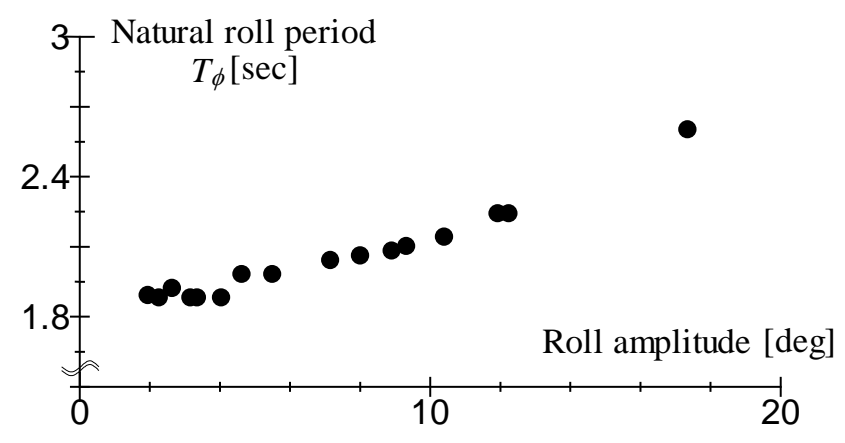

Fig. 3 M easured roll natural period.

\section{3. 横摇れ計測法}

Fig.4 に，実験状態図を示す，供試船の船首部に，横摇れ が自由となるように転がり軸受を取り付け,この軸に二本の 弾性ロープを繋ぎ曳航する. 横摇れ軸は重心高さとし, 曳航 時に弾性ロープが水平となるように調整する. 運動は, 重心 位置に設置した慣性計測機器(CROSSBOW NAV 440)で計測 する.また，波高は曳引台車上に設置したサーボ式波高計で 計測する.

造波機で波を発生させた後, 模型船停止位置まで波が到達 するのを待ち, 曳航を開始する. 運動の計測は, 模型船が静 止している状態から始め, 水槽の造波機と反対側の消波ビー チからの反射波が模型船に追いつく前に終了する.

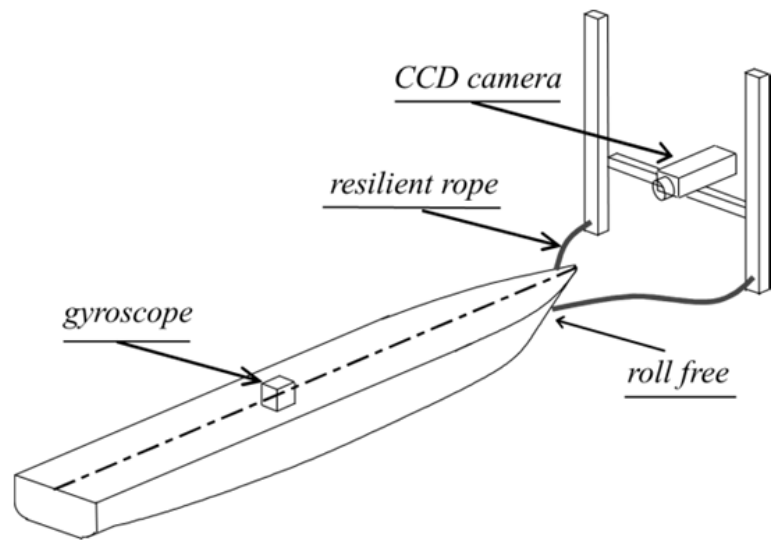

Fig. 4 Schematic view of experiment.

\section{4. 規則波中横摇れ計測}

出会い波周期 $T_{e}$ と微小振幅時横摇れ固有周期 $T_{\phi}$ の比 $T_{e} / T_{\phi}$ が 0.5 付近で, 横摇れ計測を行った. 船速は一定とし, 荒天 中を航行していると考えて実船で $7 k t(F n=0.083$, 模型スケ 一ルで $0.370 \mathrm{~m} / \mathrm{sec}$ ) とした. 入射波の波長を系統的に変化さ せ，出会い波周期が供試船の微小振幅時横摇れ固有周期の 1/2 を含む 0.8 1.35sec となるようにした.また，波高を 0.01 0.05m の範囲で系統的に変化させた. Table 2 に実験状 態を示す.

Table 2 Experimental condition.

\begin{tabular}{|c|c|}
\hline $\mathrm{Fn}$ & 0.083 \\
\hline wave period: $\mathrm{T}_{\mathrm{w}}[\mathrm{sec}]$ & $0.99 \sim 1.55$ \\
\hline $\mathrm{T}_{\mathrm{e}} \mathrm{T}_{\phi}$ & $0.42 \sim 0.71$ \\
\hline wave height: $\mathrm{H}_{\mathrm{w}}[\mathrm{m}]$ & $0.01,0.02,0.03,0.04,0.05$ \\
\hline
\end{tabular}

$T_{e}$ : encounter wave period $[\mathrm{sec}]$ $\mathrm{T}_{\phi}:$ natural roll period [sec] 
Fig.5 に，横摇れ計測結果の一例を示す。同図上段は外乱 を与えても周期的な横摇れが生じない場合（Case 1)，中段 は外乱が無くても周期的な横摇れが生じる場合（Case 2）， 下段はある程度以上の大きさの外乱を与えたときに周期的 な横摇れが生じる場合（Case 3）である. 本研究では, 同図 中段および下段の様な結果を, 周期的な横摇れが生じる場合 とした．以下では，これら結果は区別できるように示す.

Fig.6 に, 実験で計測された周期的な横摇れの振幅角を示 す. 縦軸は無次元横摇れ振幅角（横摇れ振幅角を入射波の波 数と波高で割った），横軸は $\mathrm{T}_{\mathrm{e}} / \mathrm{T}_{\phi}$ （出会い波周期と微小振 幅時横摇れ固有周期との比）である. $\mathrm{T}_{\mathrm{e}} / \mathrm{T}_{\phi}=0.5$ では波高の 大小にかかわらず横摇れが生じ, それ以外では波高が小さい と横摇れが生じない結果となった. 同じ波高での横摇れ振幅 角は, $\mathrm{T}_{\mathrm{e}} / \mathrm{T}_{\phi}<0.5$ では $\mathrm{T}_{\mathrm{e}} / \mathrm{T}_{\phi}=0.5$ の結果に比べて小さく, $\mathrm{T}_{\mathrm{e}} / \mathrm{T}_{\phi}>0.5$ では一旦小さくなったあと大きくなる傾向が見ら れる.なお, 振幅角が再び大きくなる周波数域での横摇れは, Fig.5 中 Case 3（ある程度以上の外乱が与えられて周期的な 横摇れが生じる場合）であった。

Fig.7 に, 田口らによる一般的なポストマナマックスコン テナ船（正面線図と GZ 曲線は付録 A 1 参照）を用いたパラ メトリック横摇れの計測結果 ${ }^{1)}$ を示す。この結果では, 周期 的な横摇孔は $0.4<T_{e} / T_{\phi}<0.6$ で生じ, 振幅角は $T_{e} / T_{\phi}=0.5$ 付近 で最大で, $T_{e} / T_{\phi}$ の増減に伴い減少する. 田口らの結果と本 研究の結果 Fig.6 を比べると, $T_{e} / T_{\phi}<0.5$ では同様の傾向が得 られているが, $\mathrm{T}_{\mathrm{e}} / \mathrm{T}_{\phi}>0.5$ では田口らの結果より横摇れ振幅 角が大きい. $\mathrm{T}_{\mathrm{e}} / \mathrm{T}_{\phi}>0.5$ で, 田口らと異なる結果が得られた のは, 供試船の復原力曲線が横傾斜角の増加に伴い線形復原 力に比べて小さくなる非線形性を有し, 横摇れ振幅角の増加 に伴い横摇れ固有周期が長くなったためだと考えられる.

次に, 入射波の波長を一定とし, 系統的に速度を変化させ て横摇れを計測した. Table 3 に実験状態を示す. 波長船長 比を $\lambda / \mathrm{L}_{\mathrm{pp}}=1.0$ とし, $\mathrm{T}_{\mathrm{e}} / \mathrm{T}_{\phi}=0.5$ となる船速 $0.340 \mathrm{~m} / \mathrm{sec}$. $(\mathrm{Fn}=0.077$, 実船で $6.5 \mathrm{kt})$ から系統的に速度を下げて実験 を行った. なお, 前進速度が遅いほど波との出会い周期は長 くなる. 実験結果をFig.8に示す. 前進速度が遅いほど波と の出会い周期が長くなるにもかかわらず, 出会い周期の 2 倍周期の横摇れが発生し, その振幅角は増加する結果が得ら れた。

Table 3 Experimental condition.

\begin{tabular}{|c|c|c|c|}
\hline $\mathrm{Fn}$ & 0.000 & 0.032 & 0.077 \\
\hline $\mathrm{T}_{\mathrm{e}} / \mathrm{T}_{\phi}$ & 0.60 & 0.55 & 0.5 \\
\hline
\end{tabular}

この原因を確かめるため, まず前進速度と横摇れ減衰力の 関係を調査した. Fig.9 に, 池田らの方法 ${ }^{5)}$ にるる横摇れ減 衰力推定結果を示す. 横摇れ減衰力は, 前進速度の減少にほ ぼ比例して減少することが確認できる.これは, 前進速度に よって生じる揚力成分が減少するためである.このことから 前進速度が遅いほど横摇れ振幅角が大きくなる可能性があ
ることがわかる.

さらに,この横摇れがパラメトリック横摇れであると考え,

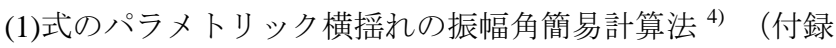
A 2 参照) による計算を行った。計算結果をFig.10 に示す.

$$
\mathrm{B}_{44}\left(\phi_{\mathrm{a}}\right)=\frac{\mathrm{W} \Delta \mathrm{GM}}{2 \omega_{\mathrm{e}}}
$$

ここで, $B_{44}$ は横摇れ減衰力係数, $\phi_{a}$ は横摇れ振幅角[deg], $\mathrm{W}$ は排水量 $[\mathrm{kgf}], \Delta \mathrm{GM}$ は復原力変動量, $\omega_{\mathrm{e}}$ は出会い波円周 波数 $[\mathrm{rad} / \mathrm{sec}]$ である。なお, 復原力変動量は船速によって変 わらないと仮定して, Fig.6 中 $\mathrm{F}_{\mathrm{n}}=0.032, \mathrm{H}_{\mathrm{w}}=0.05 \mathrm{~m}$ での横摇 れ振幅角計測結果をもとに求めた。 また, 横摇れ減衰力は池 田らの方法で推定した. 横摇れ振幅角の計算結果は, 同図中 に示す実験結果 $\left(\mathrm{H}_{\mathrm{w}}=0.05 \mathrm{~m}\right)$ と定性的に一致することが確 認できる.

以上の結果から, 系統的に速度を下げた実験で見られた横 摇れ振幅角の増加は, 速度が遅いほど横摇れ減衰力が減少し て横摇れ振幅角が増加する一方, 供試船の横摇れ固有周期が 振幅角の増加に伴って長くなりパラメトリック横摇れが発 生したと考えられる.

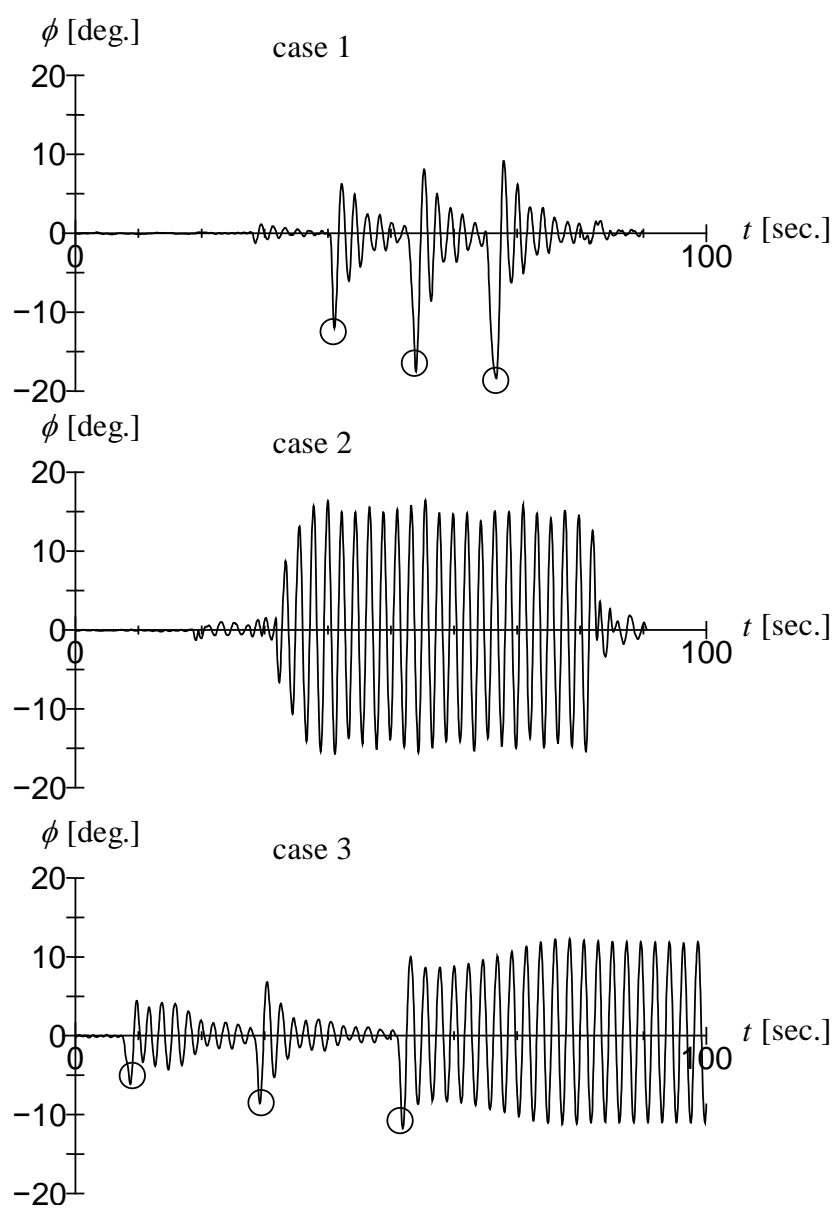

Fig. 5 Time histories of measured roll motions in regular wave. ( $\bigcirc$ : disturbance) 


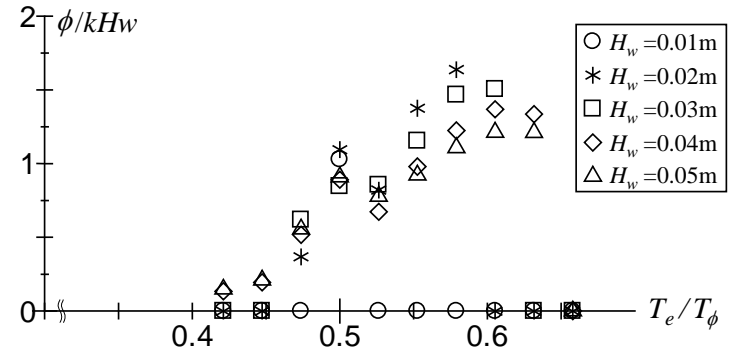

Fig. 6 Measured roll amplitude in regular head waves at $\mathrm{Fn}=0.083$. (Case 3: $\mathrm{T}_{\mathrm{e}} / \mathrm{T}_{\phi}=0.53,0.55,0.58$ at $\mathrm{H}_{\mathrm{w}}=0.02 \mathrm{~m}$ and $\mathrm{T}_{\mathrm{e}} / \mathrm{T}_{\phi}=0.61$ at $\mathrm{H}_{\mathrm{w}}=0.03 \mathrm{~m}$ and $\mathrm{T}_{\mathrm{e}} \mathrm{T}_{\phi}=0.63$ at $\mathrm{H}_{\mathrm{w}}=0.04 \mathrm{~m}$ )

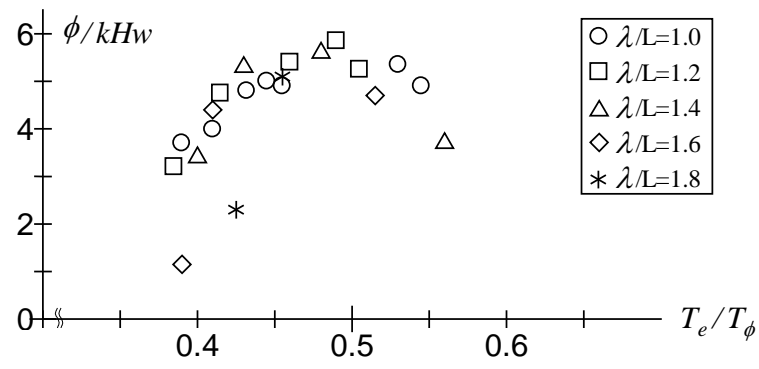

Fig. 7 Measured roll amplitude in regular head waves at $\mathrm{H}_{\mathrm{w}}=0.11 \mathrm{~m}$. (citation from Fig. 6 in reference 1)

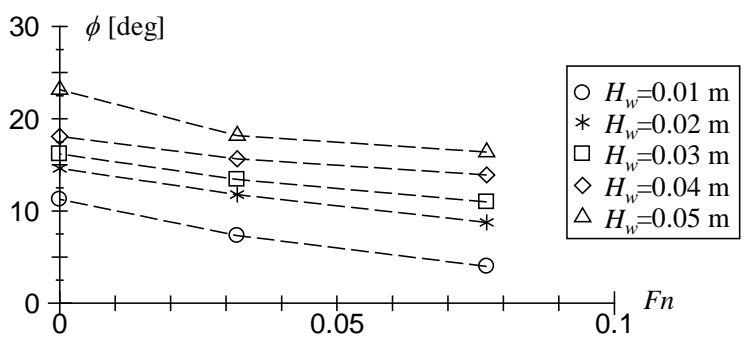

Fig. 8 Measured roll amplitude.

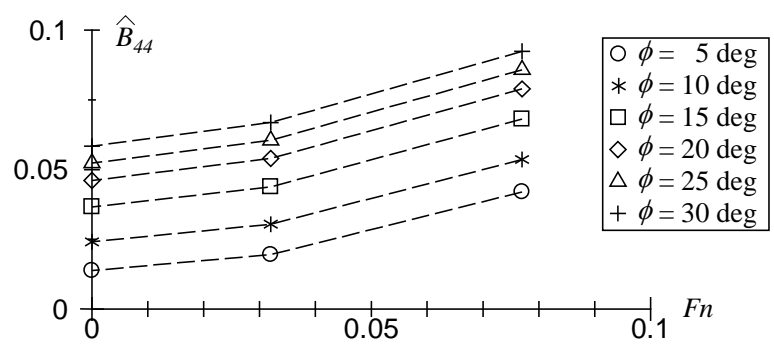

Fig. 9 Estimated roll damping coefficient by Ikeda's method.

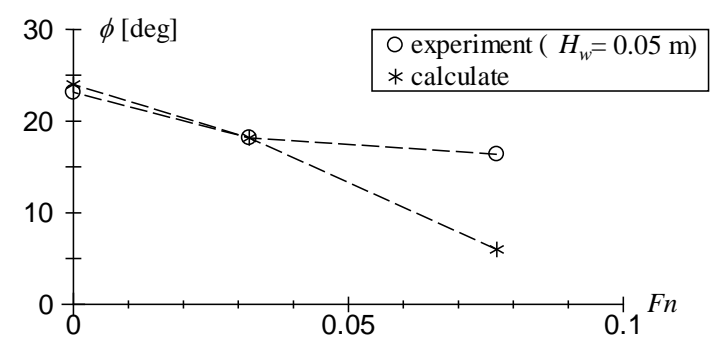

Fig.10 Estimated results of roll amplitude by $\mathrm{Eq}(1)$.

\section{5. 不規則波中横摇れ計測}

(2)式の有義波高 $\mathrm{H}_{1 / 3}$ をパラメータとし, 有義波高の増加 に伴い平均波周期は長くなる特徴を持つ Pierson-M oskowit spectrum を円周波数 1 15 rad/sec の範囲で 1000 等分し, それ ぞれの周波数の正弦波を重祆合わせて不規則波を作成する. なお, 各周波数成分波の位相差は乱数を発生させて決定する.

$$
S(\omega)=\frac{8.1 \times 10^{-3} \times g^{2}}{\omega^{2}} \exp \left(-\frac{3.11 / \mathrm{H}_{1 / 3}^{2}}{\omega^{4}}\right)
$$

ここで, $\mathrm{S}(\omega)$ はパワースペクトラム $\left[\mathrm{m}^{2}\right], \omega$ は波の円周波数 [ rad/sec]である.

実験では, 有義波高の異なる 3 種類の不規則波を発生させ, そのピーク周波数の波との出会い周期が, 供試船の微小振幅 時横摇れ固有周期の 2 分の 1 前後となるように, 有義波高を 0.04，0.05，0.06m とした. Fig.11に発生させた不規則波を計 測しパワースペクトラムを算出した結果を示すとともに, 造 波に用いた理論值を造波に使用した周波数範囲とともに示 す. 実験結果では理論值にないピークがみられるが，有義波 高の増加に伴って平均波周期が長くなる特徵は確認できた のでそのまま実験を行うこととした.

不規則波中での運動計測時間は，水槽の長さの制約上 40 秒とし，運動計測回数（=不規則波の作成個数）を20 回と した. なお,この回数は各計測データの分散の平均值の収束 性より決定した（付録 A 3 参照）。

Fig.12に，横摇れ振幅角の発生確率を有義波高毎に示す. なお，今回の実験では有義波高 $0.04 \mathrm{~m}$ では，10 度を超える 横摇れは発生しなかった。同図より，有義波高が高い方が, 大きな横摇れが発生する確率が高いことがわかる。

Fig.13，14 に，有義波高 $0.06 \mathrm{~m}$ での波高と横摇れの計測例 を示す, Fig.14 に発生しない場合の計測例を示す。それぞれ の図に，区間 $t_{1} ， t_{2}$ での波との平均出会い周期の $\overline{T_{e}}$ と微小振 幅時横摇れ固有周期 $T_{\phi}$ との比を示す. Fig.13 中区間 $t_{1}$ の波 群の平均出会い波周期は 0.5 より小さく, このような波群と 遭遇しても横摇れは生じない.一方, Fig.14 中区間 $\mathrm{t}_{2}$ の波群 の平均波周期は 0.5 より長く, このような波群と遭遇すると 一摇れごとに出会い波周期の 2 倍周期の横摇れが生じる.

(2)式の Pierson-M oskowitz spectrum では，有義波高の増加 に伴い平均波周期は長くなり， $\mathrm{T}_{\mathrm{e}} \mathrm{T}_{\phi}>0.5$ の成分を含む波群 の発生頻度も高くなる. 一方で供試船の場合, 復原力曲線の 非線形性のため, 波高の増加により横摇れ振幅角が増加する と横摇れ固有周期が長くなる. 以上の結果, 有義波高が増加 した場合, 波高の増加に伴い横摇れ振幅角も増加した結果横 摇れ固有周期が長くなり, パラメトリック横摇れが発生した と考えられる. 


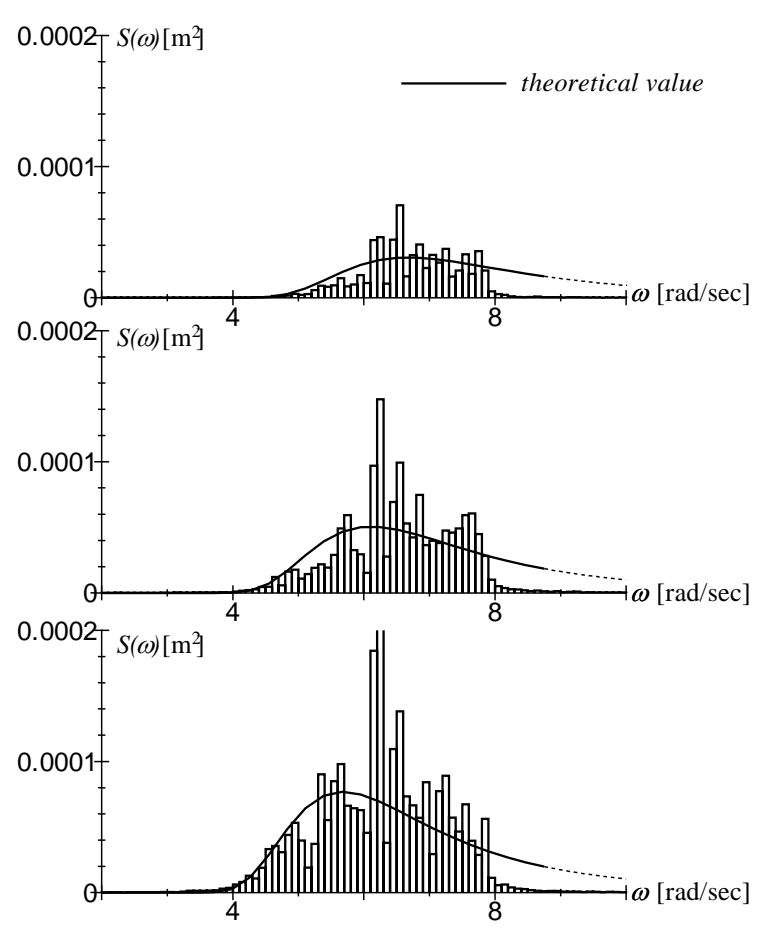

Fig.11 Measured power spectrum of wave height. (significant wave height $=0.04,0.05,0.06 \mathrm{~m}$ )

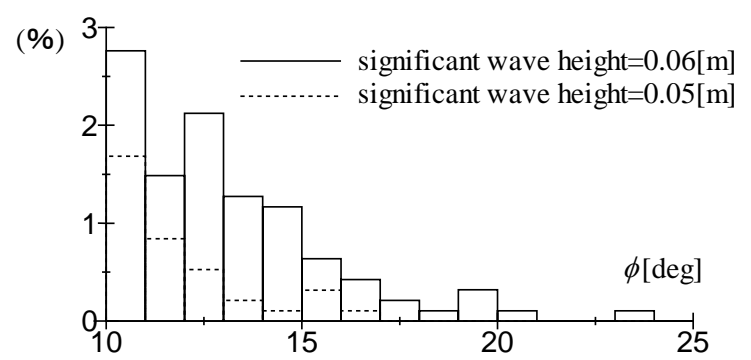

Fig.12 Probability distribution of roll amplitude. (significant wave height $=0.05,0.06 \mathrm{~m}$ )

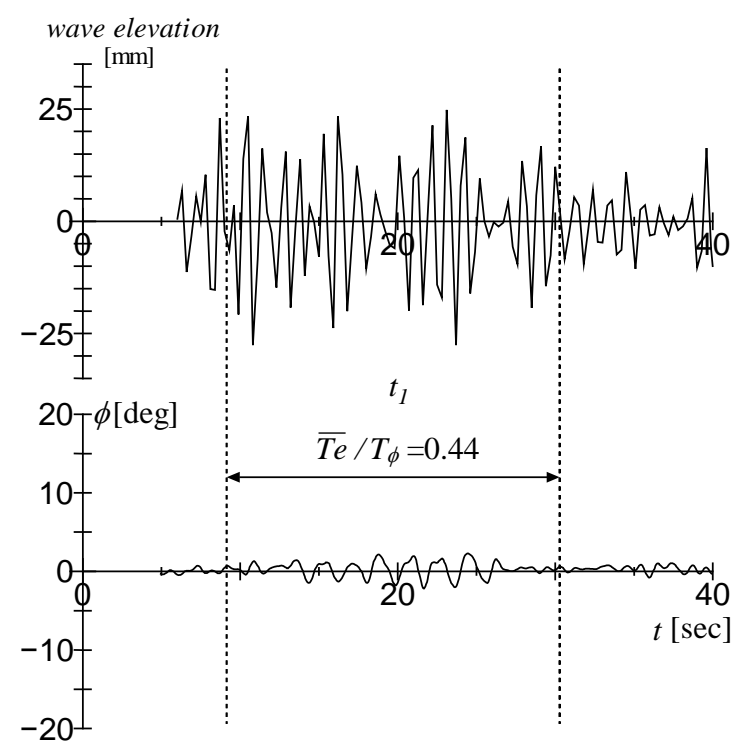

Fig.13 Time history of measured wave height and roll motion in irregular wave at $\mathrm{H}_{1 / 3}=0.06 \mathrm{~m}$ when periodic rolling does not occur.

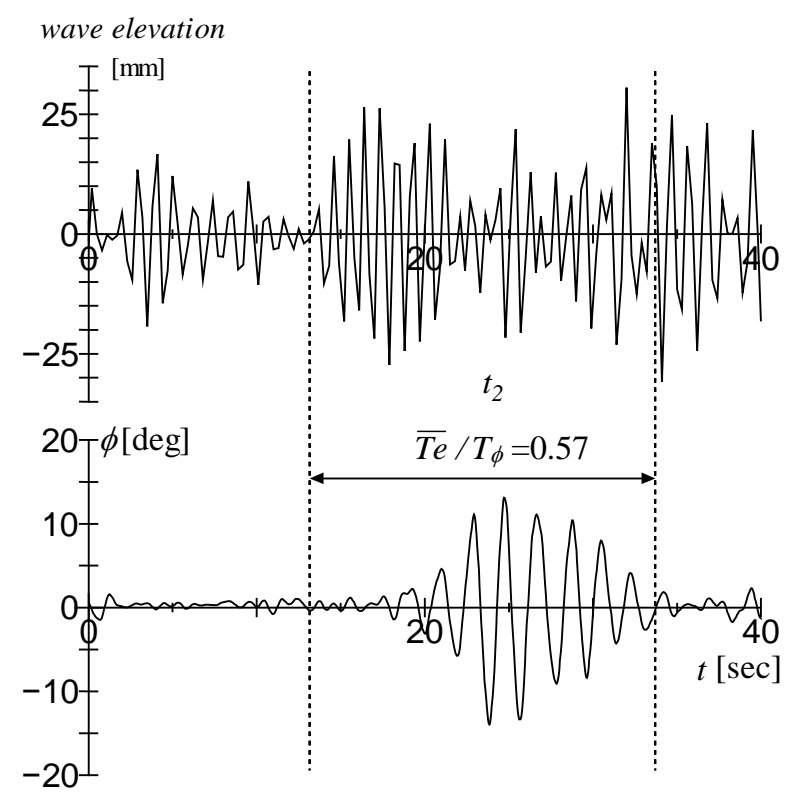

Fig.14 Time history of measured wave height and roll motion in irregular wave at $\mathrm{H}_{1 / 3}=0.06 \mathrm{~m}$ when periodic rolling occurs.

\section{6. 二周波数成分を重ね合わせた波中横摇れ計測}

不規則波中の実験からは，主要な周波数成分が $T_{e} / T_{\phi}>0.5$ の波群に出会うと横摇れが生じる結果が得られた.この横摇 れは, 波群の中の $\mathrm{T}_{\mathrm{e}} / \mathrm{T}_{\phi}>0.5$ である波との同調現象だと考え, これを確かめるために, 波高と波周期が異なる二つの正弦波 を重㸚た波の中での横摇れ計測実験を行った。

二つの異なる周期の波のうち,一方は出会い周期が微小振 幅時横摇れ固有周期の半分 $\left(T_{e} / T_{\phi}=0.5\right)$ となるようにし, も う一方はその前後となるようにした．また，二つの波の波高 は異なる.供試船の船速は $0.370 \mathrm{~m} / \mathrm{sec}(\mathrm{F} \mathrm{n}=0.083$, 実船で $7 \mathrm{kt})$ とした。

Table 4 に実験結果を示す．同表には，横摇れが生じた場 合，その振幅角を示している。縦に波高が高い波の $T_{\mathrm{e}} / T_{\phi}$, 横に波高が低い波の $T_{\mathrm{e}} / T_{\phi}$ を示している。一方の波が $\mathrm{T}_{\mathrm{e}} / \mathrm{T}_{\phi}<0.5$ で, その波高が高い場合, 横摇孔は生じていない. また, 一方の波が $T_{\mathrm{e}} / T_{\phi}>0.61$ で, その波高が高い場合も横摇 れは生じていない. 周期的な横摇れが生じた場合, その周期 は二つの波の成分のうち波高の高い波との出会い周期の 2 倍であり， $T_{\mathrm{e}} \mathrm{T}_{\phi}$ が大きいほど横摇れ振幅角は大きい，規則 波中の実験では, 表中の色つきの状態で周期的な横摇れが生 じたことを考慮すると, 表中の太枠で示寸範囲で周期的な横 摇れが生じる可能性があると予測される.

以上の結果から，不規則波においても $T_{e} T_{\phi}=0.5 \sim 0.61$ の 出会い波成分が主となる波群では，横摇孔が波群中の $\mathrm{T}_{\mathrm{e}} \mathrm{T}_{\phi}=0.5 \sim 0.61$ の波成分の 2 倍周期でパラメトリック横摇れ が発生したと考えられる. 
Table 4 M easred results.

\begin{tabular}{|c|c|c|c|c|c|c|c|c|}
\hline & & & & $\mathrm{T}_{\mathrm{e}} / \mathrm{l}$ & $\mathrm{H}_{\mathrm{w}}=$ & $01 \mathrm{~m})$ & & \\
\hline & & 0.39 & 0.45 & 0.50 & 0.55 & 0.61 & 0.66 & 0.71 \\
\hline $\bar{\varepsilon}$ & 0.39 & & & $x$ & & & & \\
\hline $\bar{\delta}$ & 0.45 & & $x$ & $x$ & & & & \\
\hline ॥ & 0.50 & 10.4 & 14.1 & & 18.4 & 15.4 & 18.3 & 16.8 \\
\hline$I^{s}$ & 0.55 & & & 8.3 & & & & \\
\hline $\mathbb{*}^{\circ}$ & 0.61 & & & 16.0 & & & & \\
\hline$\vdash$ & 0.66 & & & $x$ & & & $x$ & \\
\hline & 0.71 & & & $x$ & & & & $x$ \\
\hline
\end{tabular}

number with color: amplitude of periodic rolling [deg.]

Colored w/o number: periodic rolling occurs in regular wave

\section{7. 数值シミュレーション}

ここでは，供試船において出会い波周期が $T_{\mathrm{e}} / T_{\phi}>0.5$ の範 囲で周期的な横摇れが発生したこと, および $T_{e} / T_{\phi}=0.5$ とな る速度で周期的横摇れを起こしている状態から系統的に速 度を下げるとさらに横摇れ振幅角が大きくなった原因が, 復 原力曲線の非線形性によるものであることを, 縦波中のパラ メトリック横摇れ予測のために構築された数值シミュレー ション 2)を用いて確認する. なお, 計算に用いている横摇れ 減衰力の範囲を横摇れ振幅角 30 度までとしたので, 横摇れ 振幅角が 30 度を超える計算結果は省くこととした。

供試船を基本船型として, 排水量が等しくなるように幅喫 水比 $\mathrm{B} / \mathrm{d}$ を変更して復原力曲線を変化させた. Fig.15 に B/d を変えた船型の正面線図を示し, Fig.16にこれらの復原力曲 線を示す. なお, 4 船型とも GM が等しくなるように, 重心 高さKG を決め, その線形復原力 $G M \phi$ も同図に示している. さらに, 波浪中での $G M$ 変化の傾向を見るため, 平均的な 水面位置の上下変化に伴う水線面 2 次モーメントを利用し た波浪中 $\mathrm{GM}$ 変化量 $(\triangle \mathrm{GM})$ の簡易計算法 ${ }^{6)}$ による結果を Fig.17 に示す. Fig.16 から, B/d が小さくなると, 横傾斜角 の小さい範囲での復原力曲線の非線形性が, 弱くなることが わかる。一方Fig.17の GM は，B/d が小さくなると喫水に対 し同じ割合の水面変位に対し, $\Delta \mathrm{GM}$ が小さくなる傾向があ る.

Fig.18 に基本船型を対象として, 船速一定のもと, 入射波 の波長を系統的に変化させた（Fig.6 の実験結果と同条件） 計算結果を示す. 計算においても, 波高が低い場合は横摇れ がほとんど生じず, 波高が高くなると横摇れ振幅角が増加す る. また, $\mathrm{T}_{\mathrm{e}} / \mathrm{T}_{\phi}>0.5$ では大振幅の横摇れが生じ, この横摇 れはある程度大きな初期外乱を与えた場合にのみ生じた.こ れらの傾向は, Fig.6の実験結果と定性的に一致する.

Fig.19〜21 に，Fig.18 と同条件で，B/d を変化させた船型 の計算結果を示す. なお, 波高 4, $5 \mathrm{~m}$ の計算では横摇れ振幅 角が 30 度を超えたため, これらの波高での計算結果は省い た. 概ね横傾斜角が 30 度以下で復原力曲線に非線形性が見
られない $\mathrm{B} / \mathrm{d}=2.5$ では, $\mathrm{T}_{\mathrm{e}} / \mathrm{T}_{\phi}=0.5$ 付近を横摇れ振幅角のピー クとし $T_{e} / T_{\phi}$ の増減に伴い振幅角が減少している. そして, $\mathrm{B} / \mathrm{d}$ が次第に大きくなり復原力曲線の非線形性が強くなると, 横摇れ振幅角のピーク周波数は $\mathrm{T}_{\mathrm{e}} / \mathrm{T}_{\phi}$ の大きい方へ移動し, $\mathrm{T}_{\mathrm{e}} / \mathrm{T}_{\phi}>0.5$ で横摇れが生じることが確認できる.

Fig.22 に基本船型を対象として，入射波長一定のもと，系 統的に船速を変化させた（Fig.8 の実験結果と同条件）計算 結果を示す．基本船型に対する計算結果は，Fig.8 の実験結 果と同様に, 前進速度が遅くなることにより横摇れ振幅角は 増加し, 船速が低下寸るとともに長くなる出会い周期の 2 倍周期の横摇れが発生する結果が得られた.

Fig.23 に，基本船型と Fig.15 に示す $\mathrm{B} / \mathrm{d}=3.0$ および 2.5 の 船型に対して, 入射波長および波高一定のもと, 系統的に船 速を変化させた計算結果の比較を示寸. なお同図縦軸は, そ れぞれの船型に対し $T_{e} / T_{\phi}=0.5$ となる速度 $\mathrm{Fn}=0.077$ での横 摇れ振幅角 $\phi_{F} \mathrm{n}=0.077$ で割った值を示している. 基本船型に対 し B/d を若干小さくし復原力曲線の非線形性を弱めた $B / d=3.0$ では，船速が遅くなると横摇れ振幅角は一旦大きく なった後減少する。.さらに，B/d を若干小さくし概ね横傾斜 角が 30 度以下で復原力曲線に非線形性が見られない $\mathrm{B} / \mathrm{d}=2.5$ では，船速が遅くなると横摇れ振幅角は小さくなる ことが確認できる.

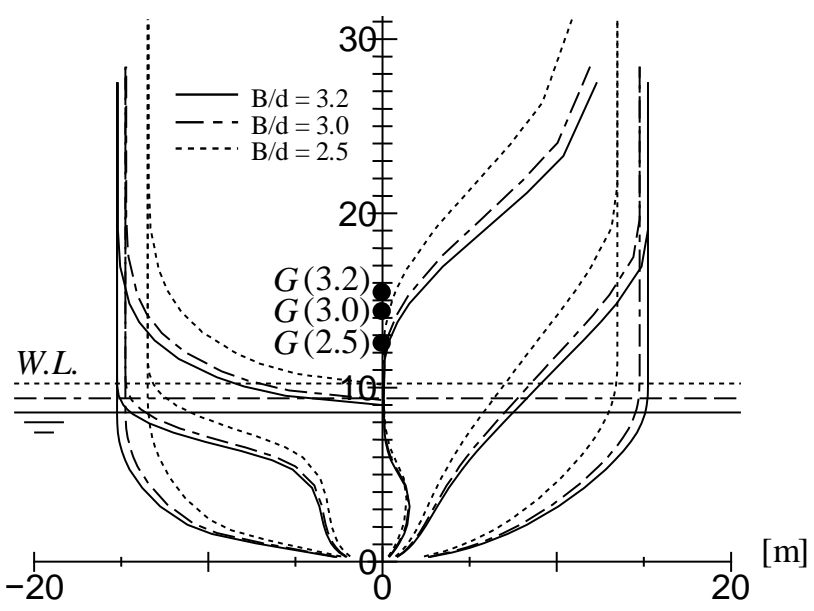

Fig.15 Body plan in real scale. $(B / d=3.2,3.0,2.5)$

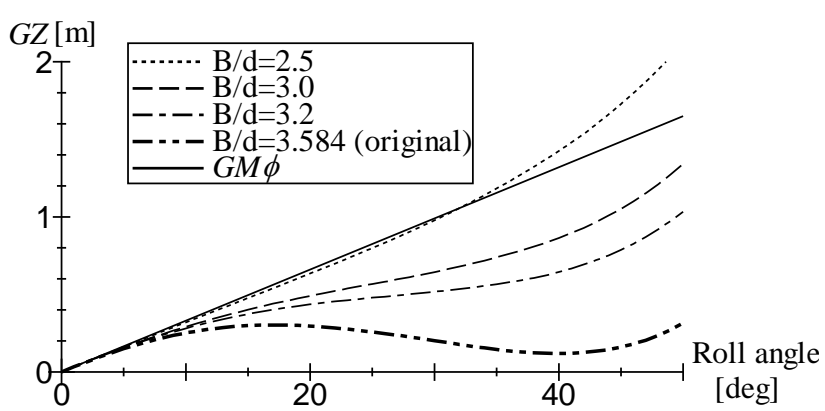

Fig.16 GZ-curves of the models with same $G M$ in real scale. $(B / d=3.584,3.2,3.0,2.5, G M=1.81 \mathrm{~m})$ 


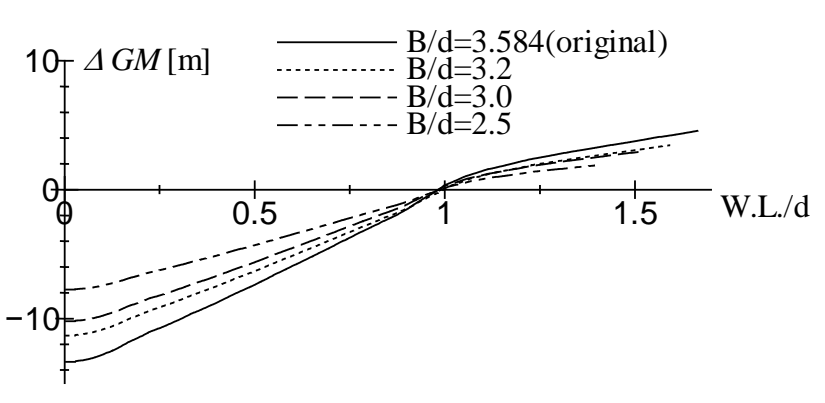

Fig.17 V ariation of GM caused by change of water surface of the models in real scale. $(B / d=3.584,3.2,3.0,2.5)$

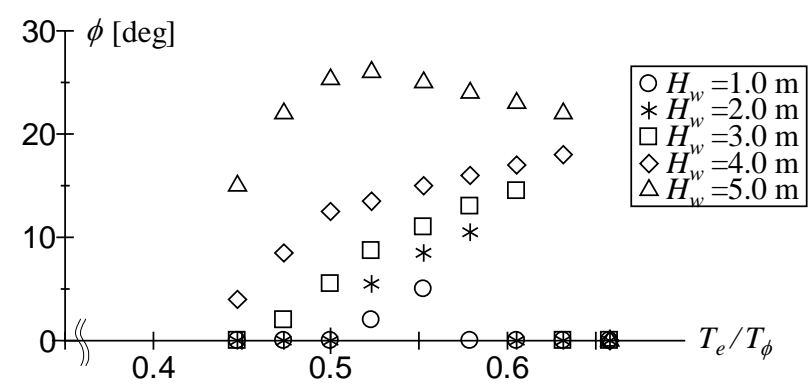

Fig.18 Calculated roll amplitude in regular head waves at $F n=0.083$ in real scale. $(B / d=3.584)$

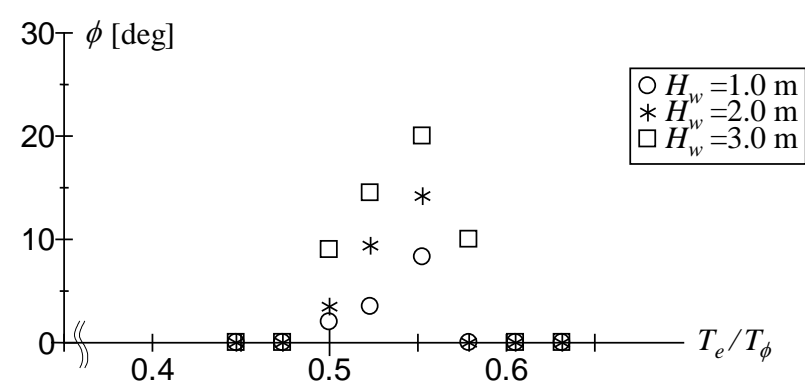

Fig.19 Calculated roll amplitude in regular head waves at $F n=0.083$ in real scale. $(B / d=3.2)$

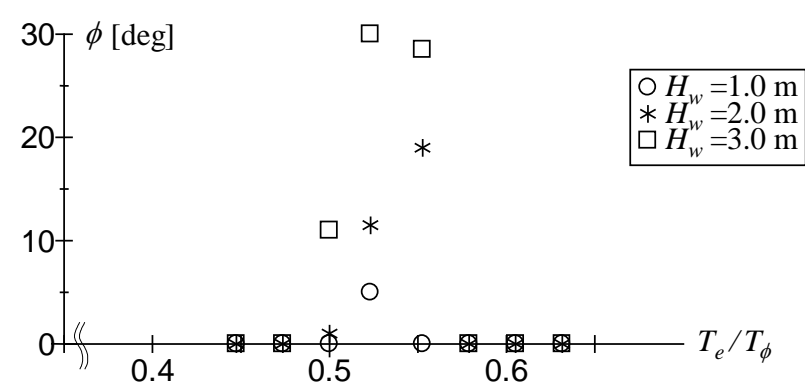

Fig.20 Calculated roll amplitude in regular head waves at $F n=0.083$ in real scale. $(B / d=3.0)$

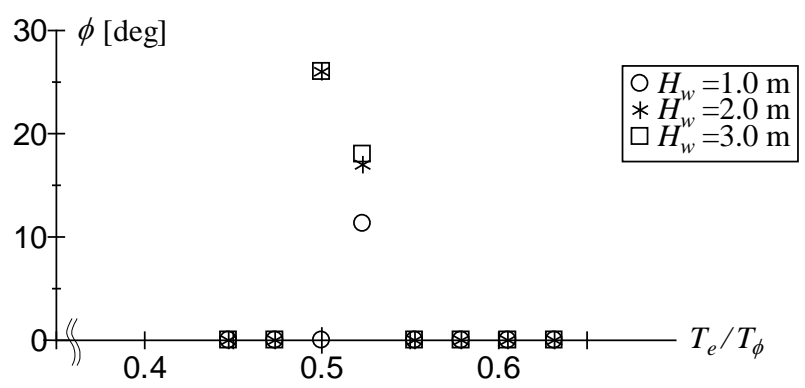

Fig.21 Calculated roll amplitude in regular head waves at $F n=0.083$ in real scale. $(B / d=2.5)$

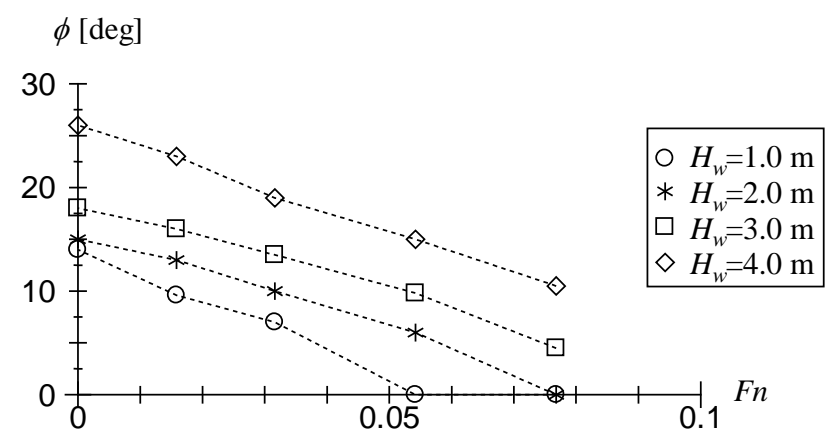

Fig.22 Calculated roll amplitude in regular head waves at $\lambda / L=1.0 .(B / d=3.584)$

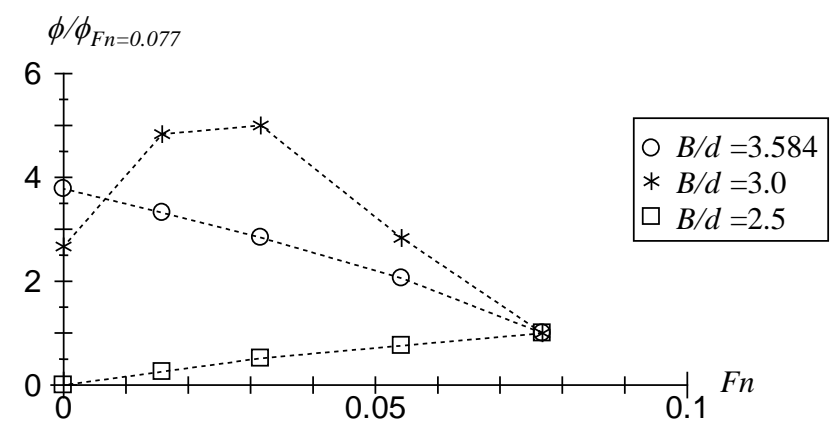

Fig.23 Calculated roll amplitude in regular head waves at $\lambda / L=1.0$ and $H_{w}=2.8 m$ in real scale $(B / d=3.584,3.0$, 2.5)

\section{8. 結言}

本研究では, 横傾斜角の増加に伴い線形復原力に比べて小 さくなる非線形な復原力曲線を持つために横摇れ固有周期 に振幅依存性がある船型を対象として, 縦波中横摇れ計測実 験を行い, その発生条件と特性について調査した. また, そ の発生原因解明のために数值シミュレーションを行い, 以下 の結論を得た。

1. 供試船では, 規則波向波中において，一般的な船型に比 べて $\mathrm{T}_{\mathrm{e}} \mathrm{T}_{\phi}>0.5$ の広い範囲で出会い周期の 2 倍周期の横 摇れが生じた。この範囲での横摇れ振幅角は, $T_{\mathrm{e}} / \mathrm{T}_{\phi}=0.5$ での值に比べて大きく, この横摇れはある程度以上の波 高と外乱が与えられた場合に生じた。 
2. 数值シミュレーションを用いて, 供試船を原型として幅 喫水比を変更し, 横傾斜角の増加に伴い線形復原力に比 べて小さくなる復原力曲線の非線形性を弱めた場合の 横摇れ発生条件の調査を行った. その結果, 復原力曲線 の非線形性が強くなるにしたがって $\mathrm{T}_{\mathrm{e}} \mathrm{T}_{\phi}>0.5$ の広い範 囲で横摇れが生じる結果が得られた。このことから, 供 試船の復原力曲線の非線形性により, 横摇れ振幅角の増 加に伴い横摇れ固有周期が長くなり, 一般的な船型に比 べて $\mathrm{T}_{\mathrm{e}} / \mathrm{T}_{\phi}>0.5$ の広い範囲でパラメトリック横摇れが生 じることが確認できた.

3. 供試船において, 波長船長比 $\lambda / L_{p p}=1.0$ の向波中を $\mathrm{T}_{\mathrm{e}} / \mathrm{T}_{\phi}=0.5$ となる速度から停止まで, 系統的に速度を変 化させた結果, どの速度でも出会い周期の 2 倍周期の横 摇れが発生した. また, その振幅角は速度が遅いほど大 きくなった。

4. この横摇れ振幅角の増加は, 前進速度が遅いほど横摇れ 減衰力が減少したためであることを, パラメトリック横 摇れの振幅角簡易計算法 ${ }^{4}$ により確認した.

5. さらに, 数值シミュレーションにより供試船を原型とし て幅喫水比を変更した船型に対して横摇れ発生条件の 調査を行い, 復原力曲線の非線形性が弱くなると, 前進 速度が遅くなれば横摇れ振幅角が小さくなることを確 認した。

6. 供試船では, 出会い周期が $T_{\mathrm{e}} / \mathrm{T}_{\phi}=0.5$ となる波ともう一 つ異なる周期の波を異なる波高で重祆合わせた向波中 では, 波高の高い波の周期が $0.5 \leqq \mathrm{~T}_{\mathrm{e}} / \mathrm{T}_{\phi} \leqq 0.61$ の場合, その出会い周期の 2 倍周期の横摇れが生じ, その振幅角 は $T_{e} T_{\phi}$ が大きい方が大きい。 このことから, 供試船に おいては, 波高の大きな波の成分が $T_{\mathrm{e}} / T_{\phi}=0.5 \sim 0.61 の$ ときに, パラメトリック横摇れが生じる.

7. 本供試船で，(2)式の Pierson-Moskowit spectrum を用い て作成した不規則向波中では, ピーク周波数が $T_{\mathrm{e}} / T_{\phi} \geqq$ 0.5 となる場合, 周期的な横摇れが生じ, 有義波高が高 い方が，大きな横摇れが発生する確率が高くなった。こ れは，(2)式の Pierson-M oskowitz spectrum が有義波高の 増加に伴い平均波周期は長くなる一方で, 供試船の場合, 復原力曲線の非線形性のため, 波高の増加により横摇れ 振幅角が増加すると横摇れ固有周期が長くなり, 有義波 高が増加した場合もパラメトリック横摇れが生じたた めである.

8. 復原力曲線が横傾斜角の増加に伴い線形復原力に比べ て小さくなる非線形性を持つ船型では, 横摇れ固有周期 が横摇れ振幅角の増加に伴い長くなるために, 波高の増 加に伴い広範囲の出会い周期でパラメトリック横摇れ が生じる可能性がある.さらに幅広浅喫水化により波浪 中での GM 変動量が大きくなる傾向がある.このよう な場合, パラメトリック横摇れの発生を抑えるためにも 横摇れ減衰力の大きさについて十分に検討する必要が ある。

\section{参 考 文 献}

1) Harukuni Taguchi, Shigesuke Ishida, Hiroshi Sawada and Makiko Minami: Model Experiment on Parametric Rolling of a Post-Panamax Containership in Head Waves, Proceedings of the Ninth International Conference on Stability of Ships and O cean V ehicles, 2006.

2) Hashimoto, H. and U meda, N.: A Study on Quantitative Prediction of Parametric Roll in Regular Waves, Proceedings of the 11th International Ship Stability W orkshop, Stability W orkshop pp.295-301, 2010.

3) 田井祥史, 大橋岳尋, 片山徹, 池田良穂 : 浅喫水船 の波浪中復原性に関する基礎的研究一復原力の非線 形性とウェザークライテリオン一, 日本船舶海洋工 学会論文集，第 14 号，2011，pp.47-54.

4) 片山徹, 谷口友基, 梅田直哉 : 高速三胴船の向波中 パラメトリック横摇れに関する実験的研究, 日本船 舶海洋工学会論文集, 第 10 号, 2009, pp.57-63.

5) Y oshiho Ikeda: Prediction M ethods of Roll Damping of Ships and Their Application to Determine Optimum Stabilization Devices, Marine Technology, Vol. 41, pp. 89-93, 2004.

6) Hirotada Hashimoto, Naoya Umeda, A kihiko Matsuda: Estimation of Parametric Roll in Random Seaways, Parametric Resonance in Dynamical Systems, pp.45-52.

7) 池田良穂, 片山徹:Windows 版船舶用 CAD システム, 船と港編集室, 2001.

8) 梅田直哉, 田口晴邦：パラメトリック横摇れ, 実海 域における船舶性能に関するシンポジウム(試験水槽 委員会シンポジウム), 2003, pp.217-235.

9) 久保巧, 梅田直哉 : クルーズ客船・フェリーの復原 性評価について, 日本クルーズ\&フェリー学会, 第 2 号, 2012, pp.29-36.

10) 中川憲治, 室津義定, 岩壷卓三 : 工業振動学（第二 版），森北出版株式会社， 1986.

11) Kerwin, J. E. : Notes on Rolling in Longitudinal Waves, International Shipbuilding Progress, V ol.2, N o.16, 1955, pp.597-614. 


\section{付 録}

\section{A1. GZ 曲線}

Fig.A1，A2 に，田口ら ${ }^{11}$ が用いたポストパナマックス船 の GZ 曲線と正面線図を, 参考文献より再掲する.

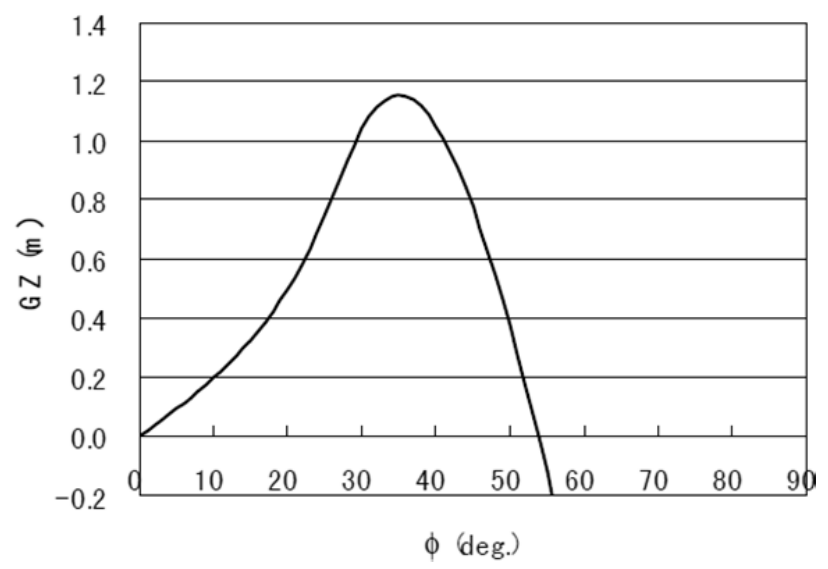

Fig.A 1 GZ-curve of the model in real scale $(G M=1.08 \mathrm{~m})$. (citation from Fig. 2 in reference 1 )

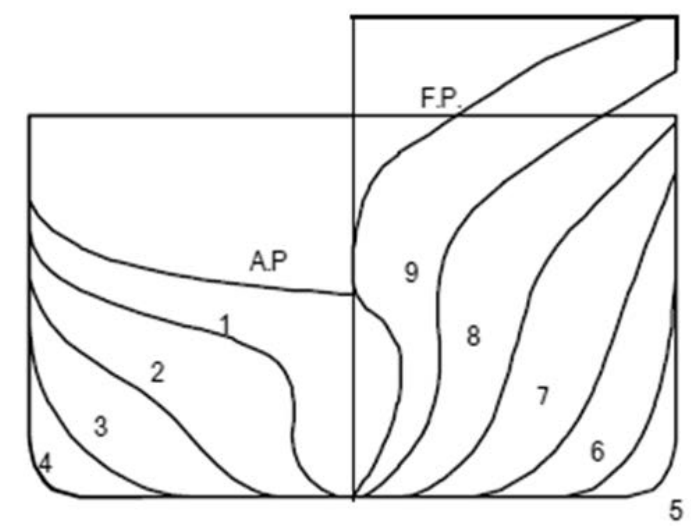

Fig.A2 Body plan.( citation from Fig.1 in reference 1)

\section{A2. パラメトリック横摇れの振幅簡易計算式について}

参考文献 4)中 5.1 節の簡易振幅計算法についての説明文 を以下に再掲する.

パラメトリック横摇れ発生時の横摇れを $\phi=\phi_{\mathrm{a}} \cos \left(2 \omega_{\mathrm{e}}^{\mathrm{t}}\right)$ と し, この横摇れを

$$
\begin{aligned}
\left(\mathrm{I}_{44}+\mathrm{a}_{44}\right) \ddot{\phi} & +\mathrm{B}_{44 \phi_{\mathrm{g}}} \dot{\phi} \\
& +\mathrm{W}\left(\mathrm{GM}_{\phi_{\mathrm{a}}}-\Delta \mathrm{GM}_{\phi_{\mathrm{a}}} \cos \left(\omega_{\mathrm{e}} \mathrm{t}-\varepsilon\right)\right) \phi=0
\end{aligned}
$$

の 1 自由度運動方程式で表す. (A 2-1)式中の $\left.\right|_{44}, a_{44}$ はそれぞ れ横摇れ慣性モーメントと付加慣性モーメント, $B_{44 \phi a}$ は等 価線形化された横摇れ減衰モーメント係数， $\omega_{\mathrm{e}}$ は波との出 会い周波数, WGM $M_{\text {a }}$ は復原モーメント係数の定常成分, $\mathrm{W} \Delta \mathrm{GM}_{\phi \mathrm{a}}$ は波浪中での復原モーメントの変動成分である. な お，同式中各項の下付の $\phi_{\mathrm{a}}$ は，横傾斜角 $\phi_{\mathrm{a}}$ での值であるこ とを示す.

(A 2-1)式を横摇れ一周期間にわたりエネルギー積分する
と，減衰モーメントによるエネルギー散逸は，

$$
\int_{0}^{\mathrm{T}_{\mathrm{n}}}\left(\mathrm{B}_{44 \phi_{\mathrm{a}}} \dot{\phi}\right) \dot{\phi} \mathrm{dt}=\pi \mathrm{B}_{44 \phi_{\mathrm{a}}} \phi_{\mathrm{a}}{ }^{2} \omega_{\mathrm{n}}
$$

となる．ここで， $\omega_{\mathrm{n}}$ は横摇れ固有円周波数である. 一方， 復原モーメント変動によるエネルギー吸収は,

$$
\begin{aligned}
& \int_{0}^{T_{\mathrm{n}}}\left\{\mathrm{W}\left(\mathrm{GM}_{\phi_{\mathrm{a}}}-\Delta \mathrm{GM}{\phi_{\mathrm{a}}}_{\mathrm{a}} \cos \left(2 \omega_{\mathrm{n}} \mathrm{t}-\varepsilon\right)\right) \phi\right\} \dot{\phi} \mathrm{dt} \\
& =\int_{0}^{T_{\mathrm{n}}}\left[\begin{array}{c}
W\left\{M_{\phi_{\mathrm{a}}}-\Delta G M_{\phi_{\mathrm{a}}} \cos \left(2 \omega_{\mathrm{n}} \mathrm{t}-\varepsilon\right)\right\} \\
\times \phi_{\mathrm{a}} \cos \left(\omega_{\mathrm{n}} \mathrm{t}\right)\left\{-\phi_{\mathrm{a}} \omega_{\mathrm{n}} \sin \left(\omega_{\mathrm{n}} \mathrm{t}\right)\right\}
\end{array}\right] \mathrm{t} \\
& =\frac{W \Delta G M_{\phi_{\mathrm{a}}} \phi_{\mathrm{a}}{ }^{2} \omega_{\mathrm{n}}}{2} \sin \varepsilon \int_{0}^{T_{\mathrm{n}}} \sin ^{2}\left(2 \omega_{\mathrm{n}} \mathrm{t}\right) \mathrm{dt} \\
& =\frac{\mathrm{W} \Delta \mathrm{GM}{ }_{\phi_{\mathrm{a}}} \phi_{\mathrm{a}}{ }^{2} \pi}{2} \sin \varepsilon
\end{aligned}
$$

となる.ここで, この項には $\varepsilon$ が残るが, 共振状態の一種で あるパラメトリック横摇れ発生時は, エネルギーの吸収効率 が最大の位相差 $(\varepsilon=\pi / 2)^{10)}$ となる.

(A 2-2)式と(A 2-3)式を用いた

$$
\mathrm{B}_{44 \phi_{\mathrm{a}}}<\frac{\mathrm{W} \Delta \mathrm{G} \mathrm{M}_{\phi_{\mathrm{a}}}}{2 \omega_{\mathrm{n}}}
$$

の不等式を満たすときパラメトリック横摇れが発生する.な お, $B_{44 \phi a}$ および $\Delta G M_{\phi a}$ は横摇れ振幅角に依存して変化する. そのため, (A2-4)式の両辺が等しくなる横摇れの振幅角は, パラメトリック横摇れの振幅を表す ${ }^{11)}$.

\section{A3. 不規則波の作成個数}

波高, 縦摇れ, 横摇れの時刻歴データから, 各データの分 散を求め,

$$
\sigma^{2}(t)=\sum_{j=1}^{n_{s}} \frac{\left(X_{j}\left(t_{j}\right)-\bar{X}(t)\right)^{2}}{n-1}
$$

その集合平均

$$
\sigma_{\text {erg }}^{2}=\frac{\sum_{i=1}^{N} \sum_{j=1}^{n} \frac{\left(X_{i}\left(t_{j}\right)-\overline{X_{i}}\right)^{2}}{n-1}}{N}
$$

を求めた ${ }^{6)}$. (A 1)(A 2)式中， $\sigma(\mathrm{t})$ は標準偏差， $\sigma_{\mathrm{erg}}$ はその集合 平均, $\mathrm{n}_{\mathrm{s}}$ は計測時間 $\mathrm{t}$ までのデータ数, $\mathrm{X}$ は計測データの平 均值である。

Fig.A3〜A5 に, 各データの分散の収束する様子を示す. 横は時間, 縦は標準偏差をその集合平均で割ったものである. 波高と縦摇れについては総標本数 20 本, 横摇れは 30 本から 求めた。(標本 1 本当たりの計測時間は 40 秒)

同図から, 標本数が 5 より多くなると, 波高および縦摇れ は収束し, 分散はほぼ収束することがわかる.一方横摇れは, 標本数が 15 を超えても，波高や縦摇れのようには安定しな い.これは, 横摇れは固有周期の半分の周期の群波に遭遇し た場合に生じ, この群波が発生する確率が低いため, かなり の標本数が必要となることを示している. そこで, 本実験で は標本数 20 程度を用いることとした。 


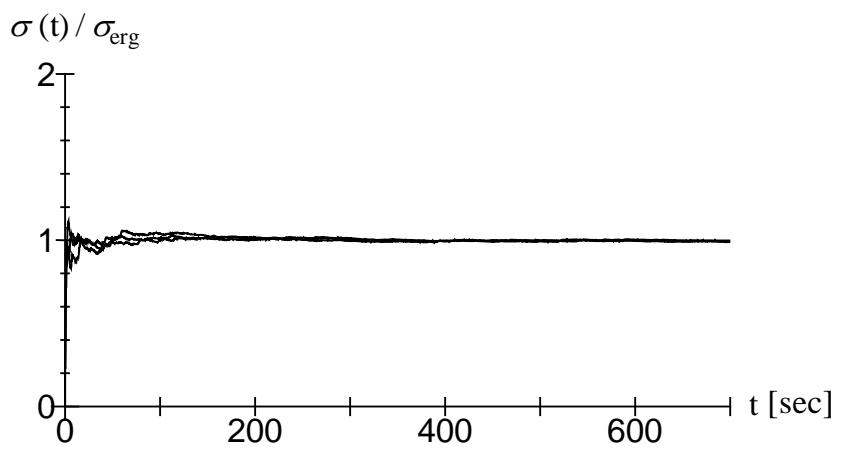

Fig.A 3 Standard deviation of wave elevation. (significant wave height $=0.04,0.05,0.06 \mathrm{~m}$ )

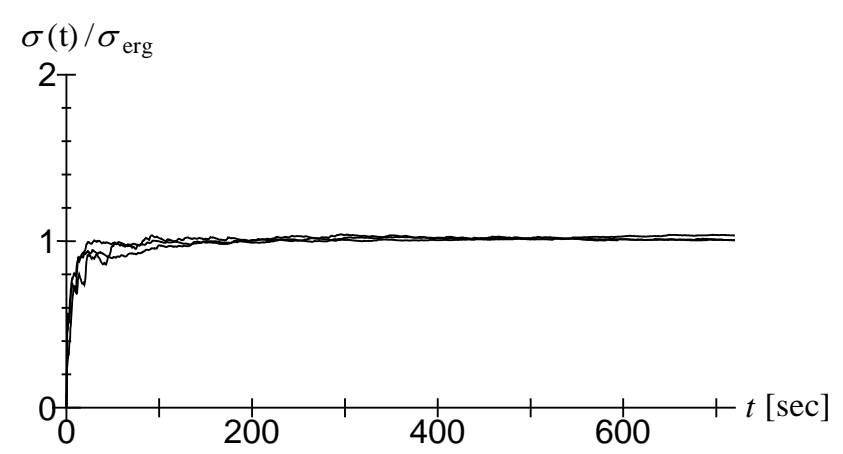

Fig.A 4 Standard deviation of pitch motion. (significant wave height $=0.04,0.05,0.06 \mathrm{~m}$ )

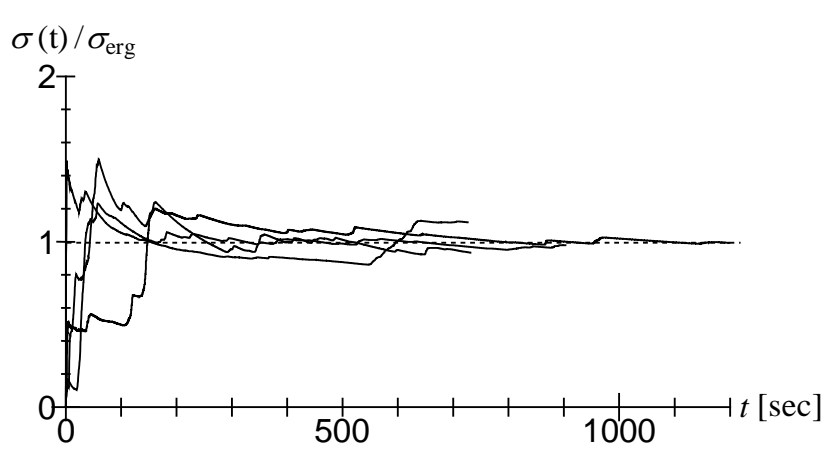

Fig.A 5 Standard deviation of roll motion. (significant wave height $=0.04,0.05,0.06 \mathrm{~m}$ ) 